\title{
STUDENT CENTRE LEARNING ( SCL) DALAM PEMBELAJARAN DI SEKOLAH DASAR
}

\author{
Oleh \\ Ni Wayan Suarjani \\ SDN 3 Bugbug \\ wayansuarjani74@yahoo.co.id
}

diterima 7 Februari 2019, direvisi 15 Februari 2019, diterbitkan 29 April 2019

\begin{abstract}
Abstrak
Tulisan ini membahas tentang pelaksanaan pembelajaran dengan SCL Penerapan model SCL dianggap sesuai dengan perubahan paradigma dari pengajaran menjadi pembelajaran. penerapan model SCL sangat efesien yakni dalam pembelajaran. Guru sebagai fasilisator mengarahkan tentang bagaimana konsep tugaas tersebut. Dengan demikian metode SCL kini dianggap lebih sesuai dengan kondisi masa kini. Yang menekankan pada minat, kebutuhan dan kemampuan individu. Model pembelajaran ini dapat mengembangkan kualita $\mathrm{s}$ sumber daya manusia yang dibutuhkan peserta didik. Serta wawasan global untuk dapat selalu beradaptasi terhadap perubahan dan perkembangan peserta didik
\end{abstract}

\section{Kata kunci : Student Centre Learning (SCL), Pembelajaran, Sekolah Dasar}

\section{PENDAHULUAN}

Pendidikan merupakan kebutuhan mutlak bagi kehidupan umat manusia yang harus dipenuhi sepanjang hayat. Tanpa pendidikan mustahil suatu kelompok manusia dapat hidup berkembang sejalan dengan aspirasi (cita-cita) untuk maju, sejahtera dan bahagia menurut konsep pandangan hidup mereka. Untuk memajukan kehidupan mereka itulah, maka pendidikan menjadi sarana utama yang perlu dikelola, secara sistematis dan konsisten berdasarkan berbagai pandangan teoritikal dan praktikal sepanjang waktu sesuai dengan lingkungan hidup manusia itu sendiri.

Ilmu pendidikan yang sering disebut dengan pedagogik merupakan suatu disiplin ilmu yang berkaitan dengan pemberdayaan, pemberbudayaan, dan pendewasaan manusia. Dalam hal ini pendidikan mempunyai tiga fungsi utama yaitu integratif, egalitarian, dan pengembangan (Ali dalam Prasojo, 05:2011). Pendidikan bertujuan untuk memberikan pengetahuan dan membetuk karakter manusia untuk memiliki ahklak mulia.

Dalam membangun pendidikan di Indonesia harus dilakukan secara bersama - sama bagi semua pihak baik pemerintah, pendidik, dan masyarakat. masyarakat memiliki peranan penting dalam membangun tujuan pendidikan yang berkwalitas. Hal tersebut selaras dengan pendapat (Astawa Temon, dalam jurnal dengan judul "memahami peran masyarakat dan pemerintah dalam kemajuan mutu pendidikan di indonesia”, 31 Agustus 2017) bahwa, masalah pendidikan sebagai proses pemanusian manusia membutuhkan sinergi antar komponen dan 
membutuhkan kesepahaman visi seluruh stake holder yang terlibat.

Fuad Ihsan (2001: 7) mengemukakan bahwa pendidikan adalah aktivitas dan usaha manusia untuk meningkatkan kepribadiannya dengan jalan membina potensipotensi pribadinya, yaitu rohani (pikir, karsa, rasa, cipta dan budi nurani) dan jasmani (panca indra serta keterampilan-keterampilan). Dari pengertian tersebut, maka manusia diharapkan dapat mengembangkan kemampuan serta meningkatkan mutu kehidupan dan martabatnya dalam rangka mewujudkan tujuan pendidikan.

Zaman posmodern yang bercirikan competitiveness tak dapat dipungkiri merupakan tantangan yang sangat berat bagi pendidikan Indonesia. Tingginya persaingan dunia memaksa kita harus mendorong peningkatan daya saing bangsa, dan untuk itu diperlukan pendidikan yang memberi pengetahuan dan pengalaman belajar bagi setiap orang secara bermakna. Sehingga proses pembelajaran harus kreatif dan inovatif untuk mencapai tujuan pendidikan yaitu mencerdaskan kehidupan bangsa.

Model pembelajaran sangat perlu dilakukan untuk mencapai kompetensi sehingga proses belajar menjadi efektif. Peran guru dalam mengajar merupakan sebagai fasilisator, yakni hanya sebagai pengarah, dan menjawab ketika peserta didik mengalami kesulitan ketika ada yang kurang dimengerti. Metode pembelajaran SCL (Student Centered Learning) , yaitu pembelajaran yang berpusat pada peserta didik.

Kurikulum yang sering berubah-ubah bertujuan untuk menyesuaikan dengan perubahan keadaan sosial masyarakat, sehingga kurikulum 2013 sesuai dengan keadaan masyarakat saat ini. Pembelajaran yang berpusat pada peserta didik ini diharapkan peserta didik untuk mengembangkan dirinya serta menambah minat dan bakat sehingga ia memahami materi pembelajaran dengan baik. Dalam proses pembelajaran pada siswa SD, penerapan model SCL sangat efesien yakni karena peserta didik diberikan tugas untuk mengamati disekitar lingkunganya. Guru sebagai fasilisator mengarahkan tentang bagaimana konsep tugaas tersebut. Hasil dari tugas tersbut kemudian dipersentasikan satu persatu sehingga semua memahami materi tersebut dengan baik.

Dengan demikian metode SCL kini dianggap lebih sesuai dengan kondisi masa kini. Yang menekankan pada minat, kebutuhan dan kemampuan individu. Model pembelajaran ini dapat mengembangkan kualitas sumber daya manusia yang dibutuhkan peserta didik. Serta wawasan global untuk dapat selalu beradaptasi terhadap perubahan dan perkembangan zaman.

\section{PEMBAHASAN}

\section{Pengertian Metode Pembelajaran} SCL

Rogers (1983), SCL merupakan hasil dari transisi perpindahan kekuatan dalam proses pembelajaran, dari kekuatan pendidik sebagai pakar mejadi kekuatan peserta didik sebagai pembelajar. Perubahan ini terjadi setelah banyak harapan untuk memodifikasi atmosfer pembelajaran yang menyebabkan peserta didik menjadi pasif, bosan dan resisten. Harden dan Crosby (2000), SCL 
menekankan pada siswa sebagai pembelajar dan apa yang dilakukan siswa untuk sukses dalam belajar dibanding dengan apa yang dilakukan oleh guru. Kurdi (109:2009), SCL atau Student Centered Learning merupakan pendekatan dalam pembelajaran yang memfasilitasi pembelajar untuk terlibat dalam proses experiential learnig. Bila pembelajar itu dapat dikategorikan ke dalam tipe-tipe activist, reflector, theorist, dan pragmatist, berarti pendekatan SCL tersebut merupakan metode yang dapat memfasilitasi pembelajar, dalam hal ini siswa sehingga secara langsung ataupun tidak dapat terlibat dalam proses pembelajaran. Dari berbagai definisi tersebut dapat disimpulkan bahwa Student Centered Learning (SCL) merupakan model pembelajaran yang menempatkan siswa sebagai pusat dari proses belajar mengajar. Model pembelajaran ini sangat berbeda dari model pembelajaran Teacher Centered Learning yang menekankan transfer pengetahuan dari guru ke siswa yang relatif bersifat pasif.

(SCL) $\begin{gathered}\text { Student-centered learning } \\ \text { merupakan }\end{gathered}$ pendekatan pembelajaran yang menempatkan peserta didik di pusat kegiatan pembelajaran. Di dalam SCL para peserta didik memiliki dan memanfaatkan peluang dan / atau keleluasaan untuk mengembangkan segenap kapasitas dan kemampuannya (prior knowledge and experience) sebagai pembelajar sepanjang hayat, melalui berbagai macam aktivitas. Student Centered Learning (SCL) adalah sebuah sistem pembelajaran yang berpusat pada murid dengan cara, guru memberikan suatu permasalahan yang sesuai dengan materi dan kemudian para murid ditugaskan untuk memecahkan masalah tersebut dengan bantuan berupa tips-tips dari sang guru dan referensi yang ada.

Menerapkan model pembelajaran SCL, ini pada awalnya digunakan oleh negara-negara maju yang bertujuan agar siswa diharapkan mampu menjadi siswa yang aktif dan mandiri dalam proses belajarnya, yang bertanggungjawab, memiliki inisiatif untuk mengetahui kebutuhan belajarnya, mampu untuk menemukan sumber-sumber informasi untuk menjawab pertanyaan tanpa bergantung pada orang lain, serta mampu mengemukakan pendapatnya. Dengan anggapan bahwa siswa adalah individu yang unik, proses, materi dan metode belajar disesuaikan secara fleksibel dengan minat, bakat, kecepatan, gaya serta strategi belajar dari tiap siswa itu sendiri.

Tersedianya pilihan-pilihan bebas ini bertujuan untuk menggali motivasi intrinsik dari dalam dirinya sendiri untuk belajar sesuai dengan kebutuhannya secara individu, bukan kebutuhan yang diseragamkan. Sebagai ganti dari proses transfer ilmu pengetahuan, siswa lebih diarahkan untuk belajar ketrampilan Learn How To Learn seperti Problem Solving, berpikir kritis dan reflektif serta keterampilan untuk bekerja dalam tim.

Pola pembelajaran yang lebih fokus adalah Teacher Centered yaitu pembelajaran lebih fokus ke guru, sehingga metode tersebut kurang efektif karena peserta didik menjadi pasif dan lebih banya mendengarkan penjelasan dari guru. Sedangkan yang sesuai dengan era sekarang adalah Student Centered Learning 
yakni pembelajaran berpusat kepada peserta didik sehingga peserta didik lebih aktif dan kreatif dalam proses pembelajaran.Dalam pembelajaran agama Hindu tersebut diharapkan peserta memiliki inisiatif untuk berkembang serta ikut aktif dalam pembelajaran. Peran guru sangat central karena guru harus memiliki kreatifitas untuk membuat peserta didik semangat dalam belajar.

Student-Centered Learning memiliki potensi untuk mendorong mahasiswa belajar lebih aktif, mandiri, sesuai dengan irama belajarnya masing-masing, sesuai dengan perkembangan usia peserta didik, irama belajar mahasiswa tersebut perlu dipandu agar terus dinamis dan mempunyai tingkat kompetensi yang tinggi. Beberapa model pembelajaran SCL adalah sebagai berikut:

\section{(1) Small Group Discussion (SGD)}

Metode diskusi merupakan model pembelajaran yang melibatkan antara kelompok mahasiswa dan kelompok mahasiswa atau kelompok mahasiswa dan pengajar untuk menganalisa, menggali atau memperdebatkan topik atau permasalahan tertentu.Dengan metode ini pengajar harus, (1) membuat rancangan bahan diskusi dan aturan diskusi. (2) Menjadi moderator dan sekaligus mengulas pada setiap akhir sesi diskusi. Sedangkan mahasiswa (1) membentuk kelompok (5 -10) mahasiswa, (2) memilih bahan diskusi, (3) mempresentasikan paper dan mendiskusikannya di kelas.

\section{(2) Role-Play and Simulation}

Metode ini berbentuk interaksi antara dua atau lebih mahasiswa tentang suatu topik atau kegiatan dengan menampilkan simbol-simbol atau peralatan yang menggantikan proses, kejadian, atau sistem yang sebenarnya. Jadi dengan model ini mahasiswa mempelajari sesuatu (sistem) dengan menggunakan model.Dengan metode ini pengajar harus, (1) merancang situasi atau kegiatan yang mirip dengan sesungguhnya, bisa berupa; bermain peran, model, dan komputer, (2) Membahas kinerja mahasiswa. Sedangkan mahasiswa mempelajari dan menjalankan suatu peran yang ditugaskan, (2) memperaktekan atau mencoba berbagai model yang telah disiapkan (komputer, prototife, 1).

\section{(3) Discovery Learning}

Metode ini berbentuk pemberian tugas belajar atau penelitian kepada mahasiswa dengan tujuan supaya mahasiswa dapat mencari sendiri jawabannya tampa bantuan pengajar. Dengan metode ini pengajar harus, (1) menyediakan data atau metode untuk menelusuri pengetahuan yang akan dipelajari mahasiswa, (2) memeriksa dan memberikan ulasan terhadap hasil belajar mahasiswa. Sedangkan mahasiswa (1) mencari, mengumpulkan, dan menyusun informasi yang ada untuk mendeskripsikan suatu pengetahuan yang baru, (2) Mempresentasikan secara verbal dan non verbal.

\section{(4) Self-Directed Learning}

Metode ini berbentuk pemberian tugas belajar kepada mahasiswa, seperti tugas membaca 
dan membuat ringkasan. Dengan metode ini pengajar harus, (1) memotivasi dan memfasilitasi mahasiswa, (2) memberikan arahan, bimbingan dan umpan balik kemajuan belajar mahasiswa. Sedangkan mahasiswa (1) merencanakan kegiatan belajar, melaksanakan, dan menilai pengalaman belajar sendiri, (2) inisiatif belajar dari mahasiswa sendiri.

\section{(5) Cooperative Learning}

Pembelajaran koperatif sesuai dengan fitrah manusia sebagai makhluk sosial yang penuh ketergantungan dengan otrang lain, mempunyai tujuan dan tanggung jawab bersama, pembegian tugas, dan rasa senasib. Dengan memanfaatkan kenyatan itu, belajar berkelompok secara koperatif, mahasiswa dilatih dan dibiasakan untuk saling berbagi (sharing) pengetahuan, pengalaman, tugas, tanggung jawab. Saling membantu dan berlatih beinteraksi-komunikasisosialisasi karena koperatif adalah miniature dari hidup bermasyarakat, dan belajar menyadari kekurangan dan kelebihan masing-masing.

Jadi model pembelajaran koperatif adalah kegiatan pembelajaran dengan cara berkelompok untuk bekerja sama saling membantu mengkontruksu konsep, menyelesaikan persoalan, atau inkuiri. Menurut teori dan pengalaman agar kelompok kohesif (kompak-partisipatif), tiap anggota kelompok terdiri dari $4-5$ orang, mahasiswa heterogen (kemampuan, gender, karekter), ada control dan fasilitasi, dan meminta tanggung jawab hasil kelompok berupa laporan atau presentasi.Sintaks pembelajaran koperatif adalah informasi, pengarahan-strategi, membentuk kelompok heterogen, kerja kelompok, presentasi hasil kelompok, dan pelaporan.Dengan metode ini pengajar harus, (1) merancang dan memonitor proses belajar mahasiswa, (2) menyiapkan kasus atau masalah untuk diselesaikan mahasiswa secara berkelompok. Sedangkan mahasiswa (1) membahas dan menyimpulkan masalah atau tugas yang diberikan secara berkelompok (2) melakukan koordinasi dalam kelompok.

\section{(6) Contextual Learning (CL)}

Pembelajaran kontekstual adalah pembelajaran yang dimulai dengan sajian atau tanya jawab lisan (ramah, terbuka, negosiasi) yang terkait dengan dunia nyata kehidupan mahasiswa (daily life modeling), sehingga akan terasa manfaat dari materi yang akan disajikan, motivasi belajar muncul, dunia pikiran mahasiswa menjadi konkret, dan suasana menjadi kondusif - nyaman dan menyenangkan. Prinsip pembelajaran kontekstual adalah aktivitas mahasiswa, mahasiswa melakukan dan mengalami, tidak hanya menonton dan mencatat, dan pengembangan kemampuan sosialisasi.

Ada tujuh indikator pembelajarn kontekstual sehingga bisa dibedakan dengan model lainnya, yaitu modeling (pemusatan perhatian, motivasi, penyampaian kompetensi-tujuan, pengarahanpetunjuk, rambu-rambu, contoh), questioning (eksplorasi, membimbing, menuntun, mengarahkan, mengembangkan, evaluasi, inkuiri, generalisasi), learning community (seluruh 
mahasiswa partisipatif dalam belajar kelompok atau individual, minds-on, hands-on, mencoba, mengerjakan), inquiry (identifikasi, investigasi, hipotesis, konjektur, generalisasi, menemukan), constructivism (membangun pemahaman sendiri, mengkonstruksi konsep-aturan, analisis-sintesis), reflection (reviu, rangkuman, tindak lanjut), authentic assessment (penilaian selama proses dan sesudah pembelajaran, penilaian terhadap setiap aktvitas-usaha mahasiswa, penilaian portofolio, penilaian seobjektif-objektifnya dari berbagai aspek dengan berbagai cara).

Dengan metode ini pengajar harus, (1) menyusun tugas untuk studi mahasiswa terjun di lapangan, (2) menjelaskan bahan kajian yang bersifat teori dan mengkaitkan dengan situasi nyata atau kerja profesional. Sedangkan mahasiswa (1) Melakukan studi lapapangan atau terjun di dunia nyata untuk mempelajari kesesuaian teori (2) membahas konsep atau teori yang berkaitan dengan situasi nyata.

\section{(7) Problem Based Learning (PBL)}

Kehidupan adalah identik dengan menghadapi masalah. Model pembelajaran ini melatih dan mengembangkan kemampuan untuk menyelesaikan masalah yang berorientasi pada masalah otentik dari kehidupan aktual mahasiswa, untuk merangsang kemampuan berpikir tingkat tinggi. Kondisi yang tetap harus dipelihara adalah suasana kondusif, terbuka, negosiasi, demokratis, suasana nyaman dan menyenangkan agar mahasiswa dapat berpikir optimal.Indikator model pembelajaran ini adalah metakognitif, elaborasi (analisis), interpretasi, induksi, identifikasi, investigasi, eksplorasi, konjektur, sintesis, generalisasi, dan inkuiri.Dengan metode ini pengajar harus, (1) Merangsang tugas belajar dengan berbagai alternatif metode penyelesaian masalah (2) Sebagai fasilitator dan motivator. Sedangkan mahasiswa (1) Belajar dengan menggali atau mencari informasi (inquiry), serta memamfaatkan informasi tersebut untuk memecahkan masalah faktual yang sedang dihadapi, (2) Menganalisis strategi pemecahan masalah.

\section{(8) Collaborative Learning (CBL)}

Metode ini memungkinkan siswa untuk mencari dan menemukan jawaban sebanyak mungkin, saling berinteraksi untuk menggali semua kemungkinan yang ada.Dengan metode ini pengajar harus, (1) Merancang tugas yang bersifat open ended, (2) Sebagai fasilitator dan motivator. Sedangkan mahasiswa (1) Membuat rancangan proses dan bentuk penilaian berdasarkan konsensus kelompok sendiri (2) Bekerja sama dengan anggota kelompoknya dalam mengerjakan tugas.

\section{(9) Project Based Learning (PjBL)}

Metode pembelajaran ini adalah memberikan tugas-tugas project yang harus diselesaikan oleh mahasiswa dengan mencari sumber pustaka sendiri.Dengan metode ini pengajar harus, (1) merumuskan tugas dan melakukan proses pembimbingan dan asesmen, (2) Sebagai fasilitator dan motivator. Sedangkan mahasiswa Mengerjakan tugas (berupa proyek) yang telah dirancang secara sistematis (2) menun-jukkan kinerja dan mempertanggungjawabkan hasil kerja di forum. 


\section{SIMPULAN}

Pembelajaran student centered learning (SCL) adalah model pembelajaran yang berfokus pada siswa sehingga peran pengajar hanya sebagai fasilitator dalam proses belajar. Model pembelajaran student centered learning (SCL), menjadikan siswa mampu untuk menjadi peserta didik yang aktif dan mandiri dalam proses belajarnya, yang bertanggung jawab dan memiliki inisiatif untuk mengenali kebutuhan belajarnya, yang menemukan sumber-sumber informasi untuk dapat menjawab pertanyaannya.

Dari uraian diatas dapat disimpulkan bahwa metode pembelajaran SCL sangat efektif digunakan dalam pembelajaran. Karena melatih peserta didik untuk berfikir tentang gambaran materi tersebut sehingga ia akan memiliki inisiatif dan kreatif dalam pelaksanaan pembelajaran. SCL merupakan pembelajaran yang berpusat kepada peserta didik sedangkan guru merupakan sebagai fasilisator sehingga peserta didik dilatih untuk aktif mengemukakan pendapatnya.

\section{DAFTAR PUSTAKA}

Astawa, Temon. 2017. Pendidikan Agama Hindu di Pasraman Non Formal Berbasis Kearifan Lokal. Denpasar: Pangkaja Jurnal Agama Hindu. Vol. 20, No.2.

Huda, Miftahul.2013. Model-model Pengajaran dan Pembelajaran. Yogyakarta :

pemanfaatannya.

Jakarta.: Rajawali Pres.

Prasojo, Diat, Lantip dan Riyanto. 2011. Teknologi informasi pendidikan. Yogyakarta: Gava Media. Pustaka Pelajar.

Sadiman, Arief S. dkk. 2010.Media Pendidikan: pengertian pengembangan dan

Surakhmad, Winarno. 1980. Interaksi Belajar Mengajar. Bandung: Jemmars. 